\title{
Long-term monitoring of Gastropoda (Mollusca) fauna in planted mangroves in central Vietnam
}

\author{
Sofya Zvonareva ${ }^{1 *}$, Yuri Kantor ${ }^{1}$, Xinzheng $\mathrm{Li}^{2}$ and Temir Britayev ${ }^{1}$
}

\begin{abstract}
Background: The aim of the research was to study the gastropod assemblage associated with a planted mangrove consisting of Rhizophora apiculata in Dam Bay (Tre Island, Nha Trang Bay, central Vietnam). Long-term changes in species composition, density, and biomass of gastropod assemblages in a planted mangrove were compared to those associated with natural mangroves.

Results: The gastropod assemblages in one planted and two natural mangrove associations were studied. Long-term monitoring (2005 to 2013) of assemblages associated with planted mangroves was also carried out. In total, 53 gastropod species in 21 families were recorded. This is comparable or even higher than in other areas of South-East Asia. In planted mangroves, R. apiculata trees were planted in mid (in 2004) and lower (2007) intertidal zones. Composition of gastropod fauna during the early period of observations (2005 to 2006) differed significantly in species richness, biomass, and abundance from the later period (2008 to 2013). Initially, the values of these parameters were low in the upper, and mid-intertidal zones and negligible in low intertidal zone. In 2008 to 2013, the values increased in the upper and mid-intertidal zones. $R$. apiculata planting in mid-intertidal zone and changes in its gastropod assemblage strongly affected those of upper intertidal zone as well. Comparison of gastropod fauna in planted mangroves and natural associations revealed significant differences. In planted mangroves, gastropods were mostly represented by eurybiotic species, also found in other not mangrove intertidal habitats, while in natural association many species were predominantly mangrove inhabitants, e.g., Potamididae, Littorinidae, and Ellobiidae. The fact that mangrove plantations in Dam Bay are highly dominated by opportunistic species, together with a paucity of predominantly mangrove-associated gastropods, suggest that the whole ecosystem is not balanced yet.

Conclusions: The gastropod assemblage found in a 9-year old mangrove plantation differed from natural mangrove associations in that the former is dominated by opportunistic eurybiotic gastropod species. This could mean that the ecosystem of planted mangroves is unbalanced and is still in a transitional state.
\end{abstract}

Keywords: Biodiversity; Biomass; Abundance; Faunal dynamics; Opportunistic species

\section{Background}

Mangroves are among the world's most productive ecosystems (Berger et al. 2008). A diverse invertebrate assemblage is associated with the mangal, with molluscs being one of the dominant components in terms of species richness, biomass, and abundance (Cantera et al. 1983, Nagelkerken et al. 2008, Sasekumar 1974). Species composition, diversity, biomass, and abundance of invertebrates change under disturbance, exploitation, or

\footnotetext{
* Correspondence: sonyazv@mail.ru

'Laboratory of Ecology and Morphology of Marine Invertebrates, A.N. Severtsov Institute of Ecology and Evolution, 33 Leninskij prosp, Moscow 119071, Russia

Full list of author information is available at the end of the article
}

rehabilitation of mangrove association (Skilleter 1996, Skilleter and Warren 2000, Bosire et al. 2004). Therefore, such parameters may reflect the status of mangrove ecosystem and can be used as an indicator of changes in both natural and planted mangroves. Comparison of invertebrate fauna of different types of mangrove stands revealed that mangrove vegetation diversity is positively correlated with associated fauna diversity, and in mature mangrove stands indexes of invertebrate fauna diversity are higher, whereas abundance and biomass are lower compared to newly planted stands (Macintosh et al. 2002).

The mangal is characterized by a high level of heterogeneity. Several studies were dedicated to horizontal distribution of invertebrate fauna in general and of particular 
groups in mangroves. General faunal zonation in the mangrove ecosystem was provided by Berry (1963), who distinguished a bivalve zone, a Nerita zone, an Uca zone, a Littoraria (as Littorina) zone, and burrower zone. Studies of distribution of macro- and mesofauna in tidal flats of northeast Australia revealed that the highest abundance and species diversity was in the mid-intertidal zone and lowest in the lower intertidal zone (Dittmann 2000). On the contrary, the abundance of polychaetes in the mangroves of northern Australia was highest in the lower intertidal zone and lowest in upper intertidal zone (Metcalfe and Glasby 2008).

Species composition also depends on the position of mangroves in relation to the sea shore, e.g., in the landward zone of mangrove vegetation - the most common gastropods belonged to the families Ellobiidae, Assimineidae, and Neritidae, while in the seaward fringe of mangroves Potamididae (Macnae 1968).

Molluscs and crustaceans play important roles in the mangrove ecosystem, processing mangrove-derived and algal detritus through their feeding and bioturbation activities (Bouillon et al. 2002; Kristensen et al. 2008; Lee 2008).

Gastropod molluscs in mangrove habitats show different levels of fidelity to this ecosystem: some species are predominantly recorded in mangrove habitats (although can be occasionally found in other environments), while others dwell in mangroves, as well as on intertidal and subtidal areas and mudflats (Lozouet and Plaziat 2008; Reid et al. 2008).

Despite the great importance of molluscs in the functioning of mangrove ecosystems, their diversity, biomass, and abundance in mangroves are in need of additional studies (Printrakoon et al. 2008).

Mangroves in Vietnam for centuries played a significant socioeconomic role in the lives of coastal inhabitants. They were employed as source of building material, fuel, food, and other useful products. Herbicide usage during 1962 to 1971 destroyed 104,939 hectares or 36\% of the mangrove forests of South Vietnam (Hong and San 1993). Population and economic growth after the war led to even more rapid reduction of mangrove areas. Shrimp and fish ponds, agriculture, charcoal production, and coastal water pollution caused degradation of mangrove associations and their conversion into wastelands (Hong and San 1993). In order to improve this situation, the Vietnamese government created a number of national parks and established protected areas with the aim to conserve and rehabilitate mangrove thickets, including reforestation and afforestation programs (Binh et al. 2005).

There are numerous publications on mangroves of Vietnam mainly related to socioeconomic aspects of the mangal ecosystem (Binh et al. 1997, De Graaf and Xuan 1998, Alongi et al. 2000, Johnston et al. 2000, Thu and Populus 2007, Christensen et al. 2008, Amano et al. 2009).
At the same time, the diversity and quantitative characteristics of macrobenthic fauna remain insufficiently studied (Le Vay et al. 2001, Tue et al. 2012). Only two species lists of gastropods in mangroves of Vietnam were found in the published literature: 15 species were reported in Can Gio District (Hong 2004) and 70 species in mangroves along the north coast of Vietnam (Hong and San 1993).

Geographically, the mentioned publications are dedicated to northern and southern Vietnam, while the mangrove associations of central Vietnam remain poorly examined. The peculiarity of mangroves in central Vietnam is that due to the high wave activity that affects the coast, mangroves are located only in well-protected lagoons and estuaries (Hong and San 1993). Often, they do not form a mangrove forest but are represented by a narrow belt of mangrove shrubs along the water's edge or fresh water channels.

In the vicinities of Nha Trang City in the Nha Trang Bay (central Vietnam), the program of mangrove vegetation planting started a decade ago. One of the areas was the Dam Bay on the Tre Island, where planting started in 2004. This provided a unique opportunity to examine the formation and dynamics of benthic community associated with the newly planted mangrove plants, and we launched the program of mangrove macrozoobenthos monitoring of the plantation, started in 2005 and continuing until the present. The aims of this present work were to study the species composition of gastropod assemblages associated with planted mangroves in Dam Bay, describe long-term changes (2005 to 2013) in the species composition, determine the density and biomass of gastropod assemblages in planted mangroves, and compare gastropod assemblages associated with planted mangroves with that of adjacent intertidal areas and natural mangroves.

\section{Methods \\ Study area}

Nha Trang (NT) Bay and Nha Phu (NP) Bay are both located in Khanh Hoa Province in the southern part of central Vietnam (Figure 1a). The areas around the two bays are densely populated, with about 400,000 inhabitants in Nha Trang city and several smaller settlements. Correspondingly, the coastline and aquatic areas of the bays are under strong anthropogenic impact in the form of wastewater discharge, pollutants, fishery, intensive tourist activities, and shipping.

Local climate is influenced by two monsoons determining wet (September to December) and dry seasons (January to August). The tidal regime of NT Bay is irregular diurnal with a spring tide/neap tide cycle of 14 days and a range of 1.5 to $2.0 \mathrm{~m}$. Monthly, there are around 18 to 22 days of diurnal tide and the rest are of mix-semidiurnal. During neap tide days, there is daily additional small high 


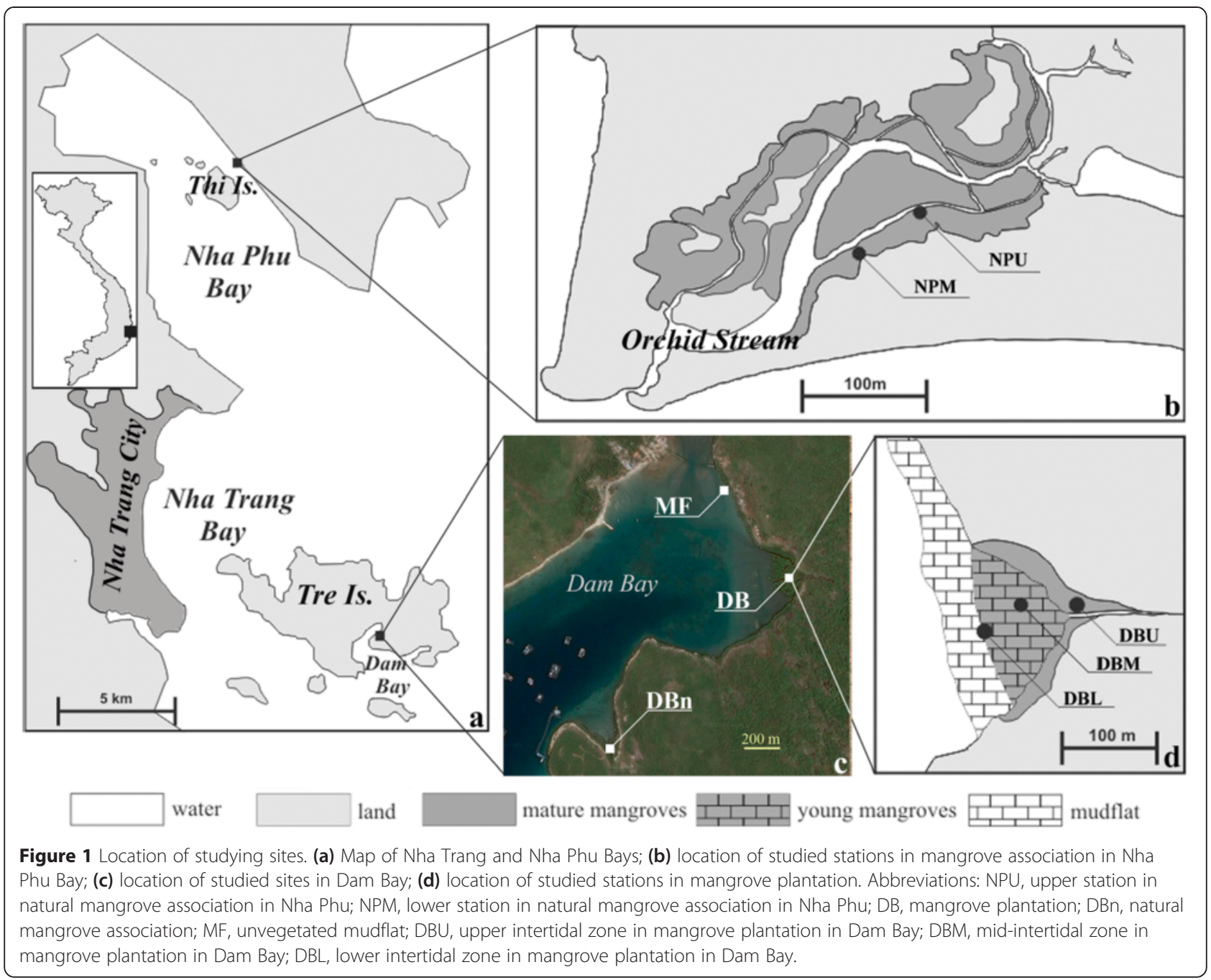

tide. During neap tide, the amplitude is about $0.5 \mathrm{~m}$ (Lan et al. 2012).

Natural mangrove stands in NT, and NP Bays are scarce and degraded due to anthropogenic impact. They still persist around shrimp and fish ponds in the mouth of the river Be within the Nha Trang city borders and in the inner part of NP Bay. The largest native mangrove association without shrimp and fish ponds is located on the north-eastern coast of NP Bay (Figure 1a).

Natural mangrove vegetation is arranged in narrow belts along the shores of small islets in NP Bay and in the inner part of Dam Bay which are located on the south side of the Tre Island (Figure 1a). These associations experience negligible freshwater intrusions in wet season. Two separated stands of artificial mangrove plantations are present in the inner part of Dam Bay (Figure 1c).

Several small settlements are located on the coast of Dam Bay, as well as numerous fish-farming floats. Despite the fact that Dam Bay area is under program of protection of marine and coastal resources, local people are fishing and collecting crabs and bivalves.

Four studying sites in different types of mangrove vegetation were selected, three in Dam Bay and one in NP Bay. The first, main study site was the mangrove plantation (below referred to as DB site, see Figure 1c,d) of Rhizophora apiculata Bl. located in the inner east coast of Dam Bay on silty-sand tidal flat with a width of 200 to $250 \mathrm{~m}$ near the belt of mature Rhizophora trees mixed with sparse Avicennia marina (Forssk.) Vierh. trees. The plantation occupies an area of approximately 1.4 ha. Temporary freshwater streams enter the inland part of plantation for a short time during the wet season, and salinity in the Bay does not deviate significantly from $33 \%$. The sampling stations were arranged in each intertidal zone in relation to the zones of trees of different age (Figure 1d). At each station, several standard frames (three to eight) were taken (each individual one is referred below as sample). The uppermost station (DBU) 
was located in the upper intertidal zone occupied by mature trees (central point of this zone is at $12^{\circ} 12^{\prime} 7^{\prime \prime} \mathrm{N}$; $\left.109^{\circ} 18^{\prime} 6^{\prime \prime} \mathrm{E}\right)$. The second station (DBM) was in the midintertidal zone occupied by $R$. apiculata trees planted at a distance of about $1 \mathrm{~m}$ in 2004 on sandy-silt mudflat $\left(12^{\circ} 12^{\prime} 5^{\prime \prime} \mathrm{N} ; 109^{\circ} 18^{\prime} 12^{\prime \prime} \mathrm{E}\right)$. The third station (DBL) was in the lower intertidal zone occupied by $R$. apiculata planted in $2007\left(12^{\circ} 12^{\prime} 5^{\prime \prime} \mathrm{N} ; 109^{\circ} 18^{\prime} 9^{\prime \prime} \mathrm{E}\right)$. Samples were taken in 2009, 2010, and 2011 in the most seaward part of the lower intertidal zone that dries out only during low spring tide where seedlings were planted in 2009. At present, the planted trees are mostly dead in that zone.

The second study site (with a single station DBn, Figure 1c) was located in a small cove with rocky shore and muddy bottom, close to Rhizophora plantation. There, mature $R$. apiculata trees form a narrow belt along the water edge. It is wider in the inner part of the basin with finer sediments, where there is a small stream $\left(12^{\circ} 11^{\prime} 50^{\prime \prime} \mathrm{N}\right.$; $\left.109^{\circ} 17^{\prime} 57^{\prime \prime} \mathrm{E}\right)$. This small natural association corresponds to the mature trees' belt in upper intertidal zone in plantation area. We investigated this site as a control (below referred to as DBn site).

The third study site is located on a non-vegetated mudflat in proximity of mangrove plantation $\left(12^{\circ} 12^{\prime} 14^{\prime \prime}\right.$ $\mathrm{N} ; 109^{\circ} 18^{\prime} 6^{\prime \prime} \mathrm{E}$ ) and was selected as a control (below referred to as MF site, see Figure 1c). We use it as a control because it is similar in terms of sediment and relief as to the area where mangrove seedlings were planted, therefore its fauna should be identical to the fauna of our DBM and DBL stations before mangroves were planted.

The study area in NP Bay $\left(12^{\circ} 24^{\prime} 22^{\prime \prime} \mathrm{N} ; 109^{\circ} 14^{\prime} 24^{\prime \prime} \mathrm{E}\right)$ was located in the central part of the north-east coast of the Bay opposite to Thi island along Orchid Stream channels. Although this area is subjected to strong anthropogenic impact, it is still the least disturbed mangrove association in the vicinity of Nha Trang City. Recreational zones are located here, and runoff in fresh water channels is produced by eutrophic ponds. This site (below referred to as NP site, see Figure 1b) was examined in order to compare it with the mangrove plantation and natural mangrove association in Dam Bay. This mangrove association is mainly formed by Rhizophora stylosa mixed with Avicennia sp., Lumnitzera racemosa Willd., Excoecaria agallocha L., Aegiceras sp., and Bruguiera gymnorhiza (L.). Samples were taken at two stations, both located in the secondary channel of the stream. The first station was located near the place where this small stream falls into the main stream, and the second station was located little upstream, and they both have full salinity during high tide. Since the structure of this mangrove association is completely different from Dam Bay, it was impossible to associate these two stations with intertidal zones of mangrove sites in Dam Bay, so we analyzed them together, as a single station.

\section{Data collection}

Quantitative samples were taken during spring (March to May) and autumn (September to October) once or twice a year, except 2007, when no samples were taken (Table 1). Samples were taken from the ground surface and did not include the molluscs, which live exclusively on tree stems and leaves. This protocol was designed, since otherwise it was impossible to obtain any comparable data.

Sampling frame (in most cases $0.1 \mathrm{~m}^{2}$ ) was placed randomly on each studying site during the low tide. Number and size of frames varied from year to year (Table 1). Also, samples were collected non-quantitatively by hand from roots, stems, and branches of mangrove vegetation, sediment surface, rocks, and dead wood when present. Inside the frame, the sediment was withdrawn to the depth of 15 to $20 \mathrm{~cm}$. It was placed in a bucket, filled with water, and stirred up with several water changes. Water was poured through the mesh with openings each diameter $0.5 \mathrm{~mm}$ for separating light fraction - detritus, plant remains, and animals, which mostly comprised polychaetes and other worms as well as some crustaceans. The light fraction was collected from the mesh, while the remaining sediment was washed through the sieve with 3-mm mesh. The residues were sorted manually in the laboratory. Living molluscs and other animals were preserved in $70 \%$ alcohol. The number of individuals of each species in quantitative samples was counted; excess liquid was removed and wet weight of each species (with the shells in the case of molluscs and brachiopods) was measured.

\section{Table 1 Number and size $\left(\mathrm{m}^{2}\right)$ of quantitative and} non-quantitative samples by years and site

\begin{tabular}{llll}
\hline $\begin{array}{l}\text { Site and year } \\
\text { of sampling }\end{array}$ & Samples in U & Samples in M & Samples in L \\
\hline$D B, 2005$ & $3 \times 0.1+$ n. s. & $3 \times 0.1+$ n. s. & $3 \times 0.1+$ n. s. \\
$D B, 2006$ & $5 \times 0.0225$ & $5 \times 0.0225$ & $5 \times 0.0225$ \\
$D B, 2008$ & $3 \times 0.1+$ n. s. & $2 \times 0.1 ; 3 \times$ & $3 \times 0.025+$ n. s. \\
& & $0.025+$ n. s. & \\
$D B, 2009$ & $7 \times 0.1+$ n. s. & $7 \times 0.1+$ n. s. & $7 \times 0.1+$ n. s. \\
$D B, 2010$ & $8 \times 0.1+$ n. s. & $8 \times 0.1+$ n. s. & $7 \times 0.1+$ n. s. \\
$D B, 2011$ & $8 \times 0.1+$ n. s. & $8 \times 0.1+$ n. s. & $8 \times 0.1+$ n. s. \\
$D B, 2012$ & $7 \times 0.1+$ n. s. & $8 \times 0.1+$ n. s. & $4 \times 0.1+$ n. s. \\
$D B, 2013$ & $8 \times 0.1+$ n. s. & $7 \times 0.1+$ n. s. & $4 \times 0.1+$ n. s. \\
$N P, 2012$ & $2 \times 0.1+$ n. s. & $2 \times 0.1+$ n. s. & - \\
$N P, 2013$ & n. s. & n. s. & - \\
$M F, 2012$ & - & $2 \times 0.1+$ n. s. & - \\
$M F, 2013$ & - & n. s. & - \\
$D B n, 2013$ & $7 \times 0.1+$ n. s. & - & - \\
\hline
\end{tabular}

DB, samples in Dam Bay (planted area); MF, mudflat in Dam Bay; NF, samples in Nha Phu; L, lower intertidal zone; $M$, mid-intertidal zone; $U$, upper intertidal zone, n. s., non-quantitative samples. 
Since the study sites differed significantly in terms of length of observations and collecting efforts, the direct comparison may be misleading. Therefore, we made a comparison of data, obtained within the single year of observations in planted mangrove association (2013) with those from two natural associations in Dam Bay (2013) and NP (2012 to 2013 combined).

\section{Data analysis}

The gastropod species were identified to species level in most cases, and information on their ecology and habitats was obtained from Reid (1986), Poppe (2008a,b, 2010), Ng and Sivasothi (1999a,b), Martins (1996), Houbrick (1985, 1992), Hylleberg and Kilburn (2003), Lozouet and Plaziat (2008), and Okutani (2000). For convenience of analysis, gastropods were conditionally divided in two major ecological groups basing on published data (Houbrick 1985; Reid 1986; Houbrick 1992; Ellison et al. 1999; Okutani 2000; Lozouet and Plaziat 2008; Reid et al. 2008): predominantly mangrove-associated and eurybiotic species. Species that are normally found in mangrove ecosystem, although can rarely be recorded in other environments, are attributed to the first group. These are represented in our material by Littorinidae, Potamididae, and Ellobiidae. Second group includes species, found by us in mangrove associations but according to published data are also common in different intertidal and subtidal habitats - mudflats, rocky shores, and dead wood.

Biomass and abundance were calculated for quantitative samples; average biomass and abundance (with standard deviation) was determined for all samples on the sampling station in a year.

Species richness is employed here as the total number of species on a station.
Average species richness per sample - average number of species, collected in each individual sample on a given station, was also calculated.

\section{Results}

Mangrove vegetation growth

Seedlings planted in mid-intertidal zone in 2004 by the autumn of 2005 reached about $0.5 \mathrm{~m}$ in height and $1.5 \mathrm{~m}$ by the autumn of 2008, producing three to five branches and aerial roots. By the autumn of 2013, trees reached height of up to $3 \mathrm{~m}$. In some places, plantings of year 2004 became almost impassible due to aerial roots. Changes in vegetation are shown in Figure 2. Seedlings planted in lower intertidal zone in 2007 have not grown sufficiently during 6 years; in autumn of 2013, they were about $1 \mathrm{~m}$ high in the lowest part of lower intertidal zone, but they were mostly dead by 2013, although some of them still have green leaves.

\section{Gastropod assemblage composition in the Nha Trang Bay} Fifty-three gastropod species belonging to 21 families were found in the bay altogether (most common and characteristic species are represented in Figures 3 and 4). Most of them belong to eurybiotic species, while 13 species can be considered as predominantly mangrove associated (Table 2).

In planted mangrove association in Dam Bay, 30 species belonging to 14 families were found during entire period of observations, while 15 species only were found in 2013. The most diverse families were Neritidae (five species), Cerithiidae (four species), and Littorinidae (four species). The eurybiotic species were dominant (see Table 2), while only five species, Littoraria spp. were predominantly mangrove inhabitants (Figure 5). The most abundant were Clithon oualaniensis, Cerithideopsilla cingulata, Clypeomorus

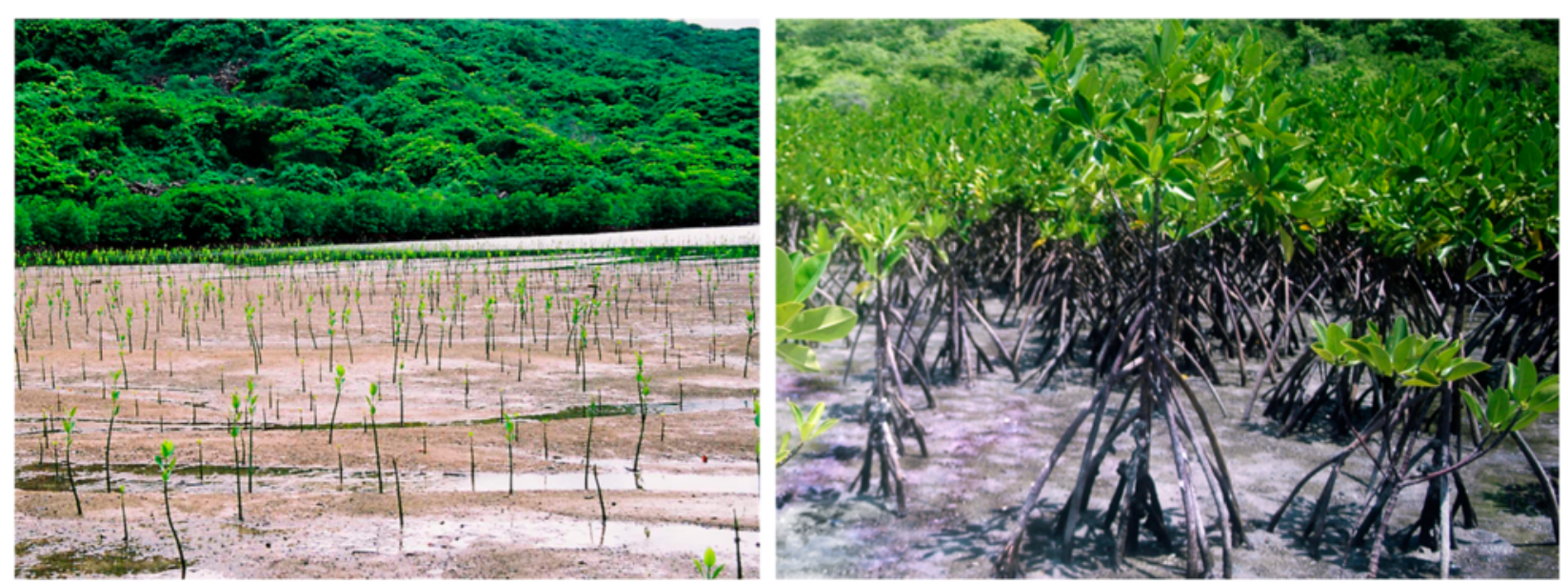

Figure 2 Mangrove vegetation growth in mid-intertidal zone of mangrove plantation in Dam Bay, Nha Trang, central Vietnam. In 2005 (left), the height of seedlings was about $0.5 \mathrm{~m}$ and in 2013 (right), the height of young trees was about $3 \mathrm{~m}$. 


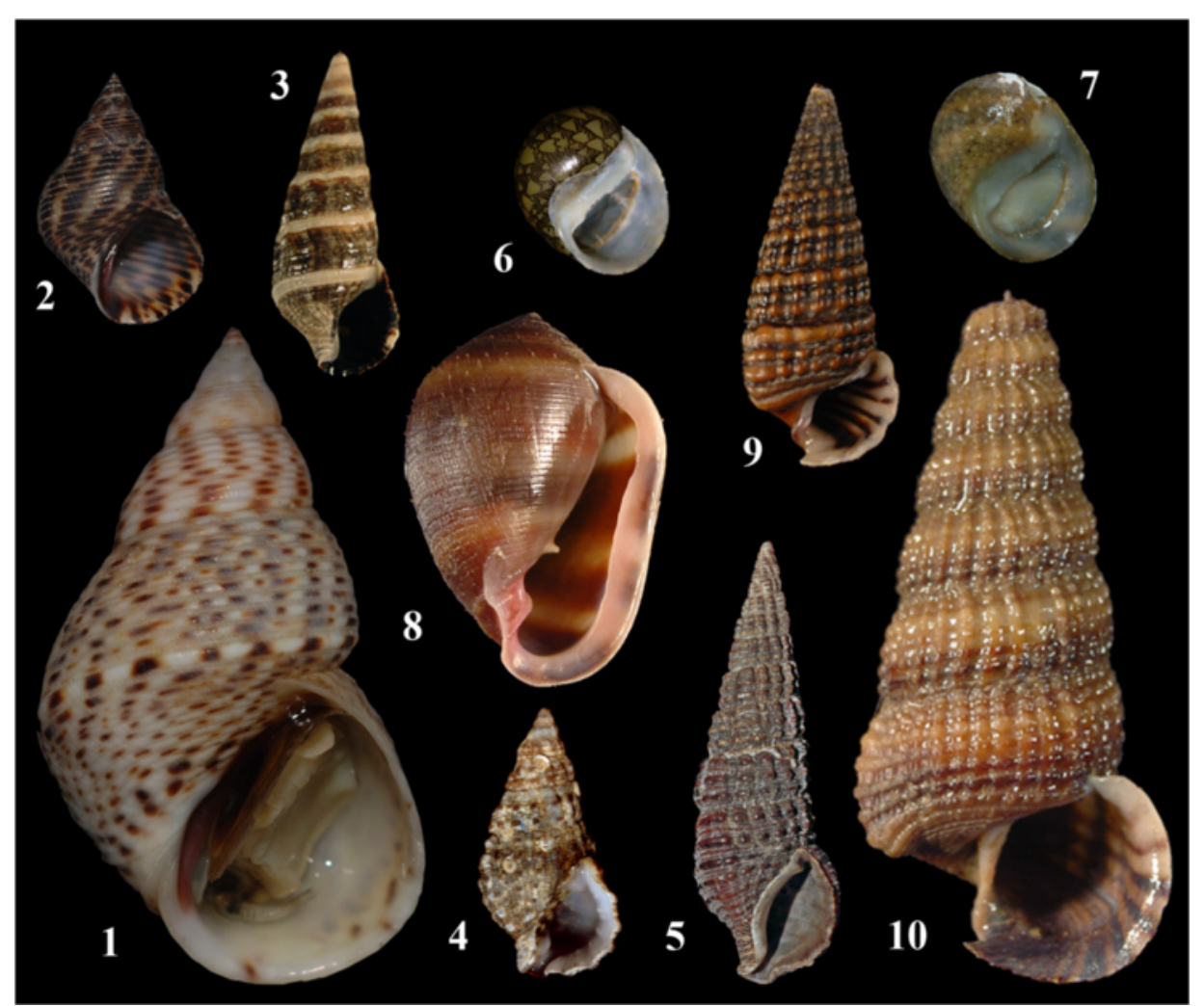

Figure 3 Shells of common eurybiotic (3 to 7, 9) and predominantly mangrove-associated species (1 to $\mathbf{2}, \mathbf{8}, \mathbf{1 0})$. $\mathbf{1}$ Littoraria lutea, $\mathbf{2}$ Littoraria intermedia, $\mathbf{3}$ Batillaria zonalis, $\mathbf{4}$ Clypeomorus bifasciata, $\mathbf{5}$ Cerithium coralium, $\mathbf{6}$ Clithon oualaniense, $\mathbf{7}$ Clithon faba, $\mathbf{8}$ Cassidula nucleus, $\mathbf{9}$ Cerithideopsilla cingulata, 10 Cerithidea quoyii.

bifasciata, and Batillaria zonalis. Both groups - inhabitants of intertidal soft bottoms (such as C. oualaniensis, $B$. zonalis, and C. cingulata), and species typical for intertidal rocky bottoms (e.g., Nerita spp., Drupella margariticola, Semiricinula turbinoides) were found.

No obvious differences were observed in species composition or species richness between upper and midintertidal zones in DB (21 and 20 species, respectively). The same situation was observed in 2013 (10 and 11 species). The lower intertidal zone differs significantly both in terms of species composition and species richness, where only eight species were found here (two - in 2013), mostly once during entire observation period. Among them, two species were common with upper and mid-intertidal zones, namely Batillaria zonalis and Clypeomorus bifasciata. At the station nearest to the sea where samples were taken in 2009, 2010, and 2011, no gastropod species were found at all.

In 2013, the difference between upper and mid-intertidal zones was not large in terms of average species richness (six species per sample in both intertidal zones) and abundance $\left(1,429.5 \mathrm{~m}^{-2}\right.$ and $1,440.3 \mathrm{~m}^{-2}$, respectively), while biomass was higher in mid-intertidal zone $\left(170 \mathrm{~g} / \mathrm{m}^{2}\right.$ and $210 \mathrm{~g} / \mathrm{m}^{2}$, respectively).
On adjacent unvegetated mudflats, only two species, namely Milda sp. and Monetaria moneta, were found. The latter species was not found in mangrove associations. In the natural Rhizophora association in Dam Bay, 19 species were collected and Cerithiidae (five species) was the most diverse family. As well as in planted mangroves, most of species were eurybiotic ones. The most abundant species were Batillaria zonalis and Clypeomorus bifasciata which are common on intertidal soft bottoms. Clypeomorus pellucida, Drupella margariticola, and Pictocolumbella ocellata were common on intertidal hard substrata. Only Littoraria scabra and L. intermedia, both of which are predominantly mangrove-associated species, were found here. The average species richness, abundance, and biomass were substantially lower (1.9 species per sample, $192.2 \mathrm{~m}^{-2}$ and 121.6 $\mathrm{g} / \mathrm{m}^{2}$, respectively) than in the plantation.

In NP, 28 species belonging to 11 families were found; the most diverse family was Potamididae (six species). The most abundant species were Clithon oualaniense and Cerithideopsilla cingulata. Among species found were species typical to intertidal soft bottoms, such as $C$. oualaniense, Clithon faba, Clypeomorus bifasciata, and C. cingulata as well as species typical for intertidal rocky bottom e.g., Nerita auriculata, Nerita cornucopia, and 


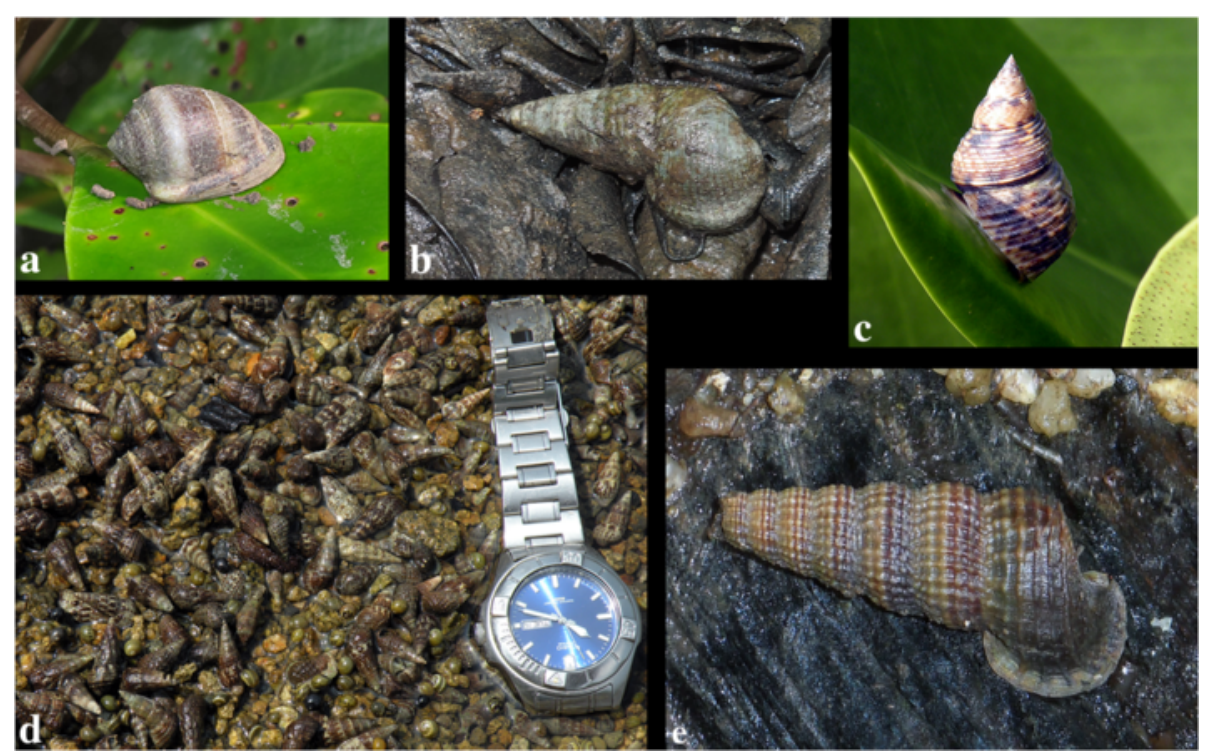

Figure 4 Some species of mangal gastropods shown alive. (a) Cassidula nucleus on Rhizophora leave in natural mangrove association in Nha Phu, (b) Terebralia sulcata on leaf litter near the roots of Rhizophora in natural mangrove association in Nha Phu, (c) Littoraria pallescens on the leaf of Rhizophora planted in 2004 in Dam Bay, (d) aggregation of Batillaria zonalis and Clithon oulaniensis on the ground between Rhizophora trees planted in 2004 in Dam Bay, (e) Cerithidea quoyii on the root in natural mangrove association in Nha Phu.

Clypeomorus pellucida. NP mangroves have higher proportion of predominantly mangrove-associated species, e.g., Littoraria spp., Cerithideopsilla microptera, Cerithidea quoyii, and Cassidula nucleus. Species abundance $\left(1,715.9 \mathrm{~m}^{-2}\right)$ was higher than in both associations in Dam Bay, while the average species richness and biomass were lower than in plantation and higher than in the natural mangrove association in Dam Bay (2.8 species per sample and $148.8 \mathrm{~g} / \mathrm{m}^{2}$ ).

\section{Long-term changes in gastropod assemblage in Dam Bay mangrove plantation}

In the mangrove plantation in Dam Bay, the total number of species varied significantly from year to year due to the occurrence of rare species, which were not recollected every year. The lowest number was in 2006 (three species) and the highest in 2011 (19 species). Predominantly mangrove-associated species first appeared in 2008 and their number grew every year (Figure 5), but even in 2013, species diversity (five species) was much lower than in the natural NP mangrove association (12 species). The number of eurybiotic gastropods changed from year to year, with highest number (15 species) recorded in 2011. This is slightly lower, than in DBn, but almost the same as in NP (Figure 5).

Over the years of monitoring, the steady growth of average species richness per sample was observed (except 2012) with the lowest in 2005 ( 0.7 species per sample) and the highest in 2013 (6 species per sample). There was little difference between upper and mid-intertidal zones (Figure 6).
In the upper intertidal zone of the mangrove plantation in Dam Bay species richness, biomass, and abundance of gastropods were very low in the first 2 years of monitoring, 2005 and 2006 (two species; $26.3 \pm 45.5 \mathrm{~g} / \mathrm{m}^{2}$; $87.9 \pm 152.2 \mathrm{~m}^{-2}$ in 2005). Then, all parameters increased substantially, the species richness and biomass reached their maxima in 2011 (11 species; $222.4 \pm 123.5 \mathrm{~g} / \mathrm{m}^{2}$ respectively) and abundance was highest in 2013 (1429.9 \pm $908.7 \mathrm{~m}^{-2}$ ) (Table 3, Figure 7). In that zone, Clithon oualaniensis was dominant in terms of biomass and abundance in 2005 to 2006, starting 2010 the biomass and abundance of Cerithideopsilla cingulata was highest, and in latest years (2010 to 2013) Batillaria zonalis became the dominant species.

In the mid-intertidal zone of mangrove plantations, species richness, biomass, and abundance of gastropods were very low in 2005 (one species; $3 \pm 2.7 \mathrm{~g} / \mathrm{m}^{2} ; 18.2 \pm 24.1 \mathrm{~m}^{-2}$ ) (Table 4). Then, these parameters increased even more dramatically than in the upper intertidal zone and reached the highest values registered in Dam Bay in 2011 (12 species; $315.6 \pm 216.6 \mathrm{~g} / \mathrm{m}^{2}$, and $1,523.9 \pm 1313.8 \mathrm{~m}^{-2}$, respectively). In 2012, a considerable decrease in abundance and biomass was observed, but in 2013, preceding values were almost reached for abundance but not for biomass (Table 3, Figure 7). High biomass was mainly due to Batillaria zonalis and Cerithideopsilla cingulata, while density was contributed mostly by $B$. zonalis and by Clithon oualaniensis.

In the lower intertidal zone, few molluscs were found both in 2010 (one species; $1.8 \pm 4.8 \mathrm{~g} / \mathrm{m}^{2} ; 1.8 \pm 6.8 \mathrm{~m}^{-2}$ ) and 2011 (three species; $0.3 \pm 0.5 \mathrm{~g} / \mathrm{m}^{2}, 4.5 \pm 9.1 \mathrm{~m}^{-2}$ ) in 
Table 2 A list of found gastropod molluscs

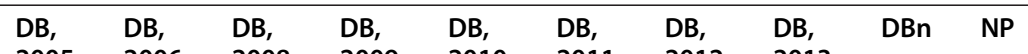

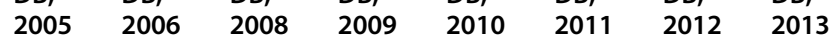

FAMILY: Lottiidae

Lottiidae gen. sp.

FAMILY: Trochidae

Monodonta sp.

FAMILY: Neritidae

Clithon oualaniense (Lesson, 1831)

Clithon faba (Sowerby I, 1836)

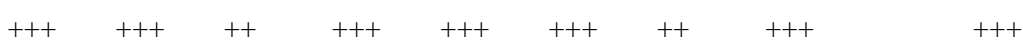

Neritina cornucopia (Benson, 1836)

$++\quad+\quad+\quad+\quad++\quad+++\quad+$

Neritina auriculata Lamarck, 1816

Neritina sp.

Nerita albicilla Linnaeus, 1758

Nerita undata Linnaeus, 1758

Nerita squamulata Le Guillou, 1841

FAMILY: Potamididae

Cerithideopsilla cingulata (Gmelin, 1791)

Cerithideopsilla djadjariensis (K. Martin, 1899)a

Cerithideopsilla microptera (Kiener, 1842) ${ }^{a}$

Cerithidea quoyii (Hombron et Jacquinot, 1848) $^{\text {a }}$

Terebralia sulcata (Born, 1774) ${ }^{a}$

Terebralia palustris (Linnaeus, 1767) ${ }^{a}$

FAMILY: Cerithiidae

Cerithium coralium Kiener, 1841

Cerithium traillii (G.B. Sowerby II, 1855)

Clypeomorus bifasciata (G.B. Sowerby II, 1855)

Clypeomorus pellucida (Hombron et Jacquinot, 1852)

Clypeomorus batillariaeformis Habe et Kosuge, 1966

Rhinoclavis vertagus (Linnaeus, 1767)

FAMILY: Planaxidae

Planaxis sulcatus (Born, 1778)

FAMILY: Batillariidae

Batillaria zonalis (Bruguière, 1792)

FAMILY: Thiaridae

Sermyla riqueti (Grateloup, 1840)

FAMILY: Littorinidae

Littoraria ardouiniana (Heude, 1885) ${ }^{a}$

Littoraria carinifera (Menke, 1830) ${ }^{a}$

Littoraria intermedia (Philippi, 1846) $^{\text {a }}$

Littoraria lutea (Philippi, 1847) ${ }^{a}$

Littoraria pallescens (Philippi, 1846) ${ }^{a}$

Littoraria scabra (Linnaeus, 1758)

Littoraria articulata (Philippi, 1846) $^{\text {a }}$

$\begin{array}{ccccccccc} & +++ & + & + & ++ & ++ & + & ++ \\ & & & & & & + & \\ +++ & +++ & +++ & ++ & + & ++ & ++ & ++ \\ + & + & ++ & ++ & ++ & ++ & ++ & ++ \\ & & & & & & & \end{array}$

+++

$+$

$+$

$++$

$++$

$++$

++

$++$ 
Table 2 A list of found gastropod molluscs (Continued)

\begin{tabular}{|c|c|c|c|c|c|c|c|c|c|c|}
\hline \multicolumn{11}{|l|}{ FAMILY: Assimineidae } \\
\hline Assimineidae gen. sp. & & & \multirow{2}{*}{\multicolumn{2}{|c|}{+}} & & \multirow[t]{2}{*}{+} & \multirow[t]{2}{*}{+} & & & ++ \\
\hline Metassiminea philippinica (O. Böettger, 1887) & & & & & & & & & & + \\
\hline \multicolumn{11}{|l|}{ FAMILY: Stenothyridae } \\
\hline Stenothyra sp. & & & & & & & & & & + \\
\hline \multicolumn{11}{|l|}{ FAMILY: Cypraeidae } \\
\hline Monetaria annulus (Linnaeus, 1758) & + & & & & & & & & & \\
\hline \multicolumn{11}{|l|}{ FAMILY: Naticidae } \\
\hline Notocochlis gualteriana (Recluz, 1844) & & + & & & + & + & & + & + & \\
\hline Naticidae gen. sp. & & & & + & + & & & & & + \\
\hline \multicolumn{11}{|l|}{ FAMILY: Ranellidae } \\
\hline Monoplex pilearis (Linnaeus, 1758) & & & & & & & + & & & \\
\hline Gutturnium muricinum (Röding, 1798) & & & & & & & & + & & \\
\hline \multicolumn{11}{|l|}{ FAMILY: Epitoniidae } \\
\hline Epitonium sp. & & & + & & & & & & & \\
\hline \multicolumn{11}{|l|}{ FAMILY: Muricidae } \\
\hline $\begin{array}{l}\text { Drupella margariticola (Broderip, in Broderip } \\
\text { et Sowerby, 1833) }\end{array}$ & & & & & & & & + & ++ & \\
\hline Tenguella musiva (Kiener, 1835) & & & & & & & & & + & \\
\hline Semiricinula turbinoides (Blainville, 1832) & & & & + & + & + & & & + & \\
\hline \multicolumn{11}{|l|}{ FAMILY: Columbellidae } \\
\hline Pictocolumbella ocellata (Link, 1807) & & & & & & & & & ++ & \\
\hline \multicolumn{11}{|l|}{ FAMILY: Nassariidae } \\
\hline Nassarius olivaceus (Bruguière, 1789) & & & & & + & & & & & \\
\hline \multicolumn{11}{|l|}{ FAMILY: Pyramidellidae } \\
\hline Milda sp. & & & & & & + & & & + & \\
\hline Otopleura auriscati (Holten, 1802) & & & & & & & & & + & \\
\hline Pyramidellidae gen. sp. & & & & + & & + & & & & \\
\hline \multicolumn{11}{|l|}{ FAMILY: Onchidiidae } \\
\hline Onchidiidae gen. sp. & + & & + & & & & & & & ++ \\
\hline \multicolumn{11}{|l|}{ FAMILY: Ellobiidae } \\
\hline Cassidula nucleus (Gmelin, 1791) & & & & & & & & & & ++ \\
\hline Laemodonta siamensis (Morelet, 1875) & & & & & & & & & & + \\
\hline Total: & 6 & 3 & 9 & 14 & 13 & 19 & 14 & 15 & 19 & 28 \\
\hline
\end{tabular}

quantitative samples. No molluscs were found in the most seaward part of the lower intertidal zone.

\section{Discussion}

\section{Vegetation growth}

According to Hong and San (1993), the growth rate of Rhizophora apiculata in Vietnam is highest between 10 and 15 years. Growth performance depends on a number of factors such as soil texture, tide amplitude, salinity and tree density. Growth was higher in areas with salinities $10 \%$ o to $20 \%$, and the growth rate declines in sites with salinities $25 \%$ o to $35 \%$ o. It was reported that in $\mathrm{Ca}$ Mau (southern Vietnam), R. apiculata younger than 10 years were replanted in the intertidal zones with silt-clay soil; the annual diameter and height increments were $0.74 \mathrm{~cm}$ and $0.81 \mathrm{~m}$, respectively. We did not measure the annual growth of planted seedlings but it is clear that the growth rate of $R$. apiculata planted in 2004 in 


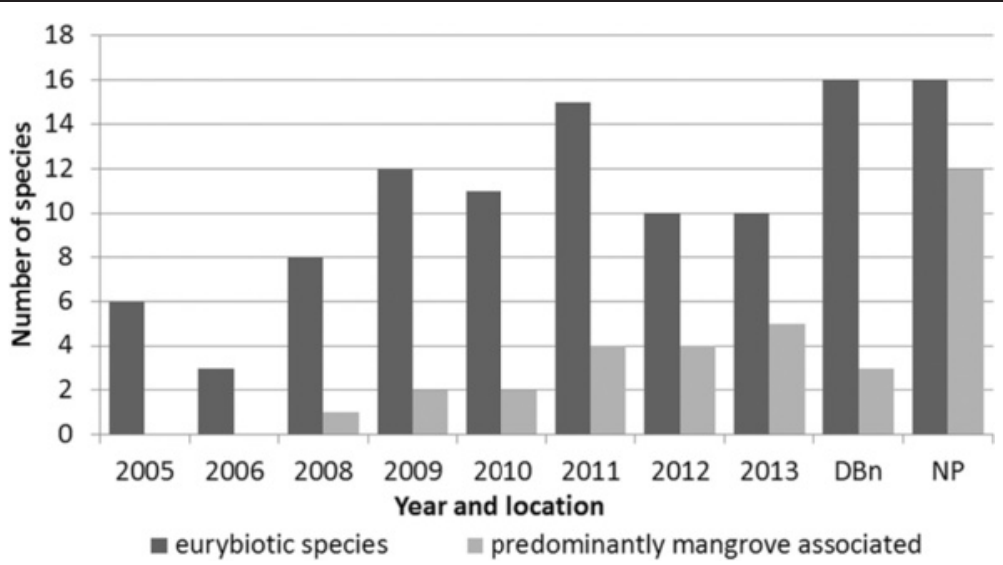

Figure 5 Proportion of predominantly mangrove-associated and eurybiotic gastropod species over the years (2005 to 2013) in mangrove plantations in Dam Bay, Nha Trang, central Vietnam, and in natural mangrove associations in Dam Bay (2013) and Nha Phu (2012 and 2013 combined).

Dam Bay was lower, since they reached only $1.5 \mathrm{~m}$ in 4 years and about $3 \mathrm{~m}$ in 10 years.

Growth rate of Rhizophora stylosa and Kandelia candel planted on sandy-clay mudflats in Ha Thin Province (central Vietnam) was low (only 0.40 to $0.87 \mathrm{~m}$ in 3-year period) due to the unfavorable soil texture and climatic conditions (Hong and San 1993). So the low growth rate of seedlings planted in 2004 in Dam Bay may be caused by the same reasons as in Ha Thin.

Seedlings planted in 2007 in lower intertidal zone in Dam Bay have not grown sufficiently during 6 years. The reasons of their poor condition may be due to the almost permanent inundation by sea water, so this site is not suitable for planting this mangrove species.

\section{Gastropod species composition}

Fifty-two gastropod species were found in three mangrove associations. It is difficult to assess species richness of studied associations due to the lack of information about faunal richness in mangroves of central Vietnam. For other parts of Vietnam, the list is available only for a natural mangrove association in northern Vietnam, where 70 species were recorded (Hong and San 1993). Analysis of this list revealed that several included species that were collected in the lower intertidal zone, e.g., Conus striatus and $C$. coronatus, both predatory species in the subtidal zone, Turbinidae, that are typical to coral reefs, one species of Viviparidae, that inhabit only fresh water, and some trochids such as Angaria delphinus (=laciniata), which normally inhabit subtidal habitats, may not have been collected alive and that these empty shells were brought to the mangroves by hermit crabs or currents. If we exclude from this list the species that are unlikely to belong to the mangrove ecosystem, we have nearly the same species number (53 species) as in our study. Therefore, the observed diversity of molluscs in mangroves of central Vietnam appears similar to that of northern Vietnam.

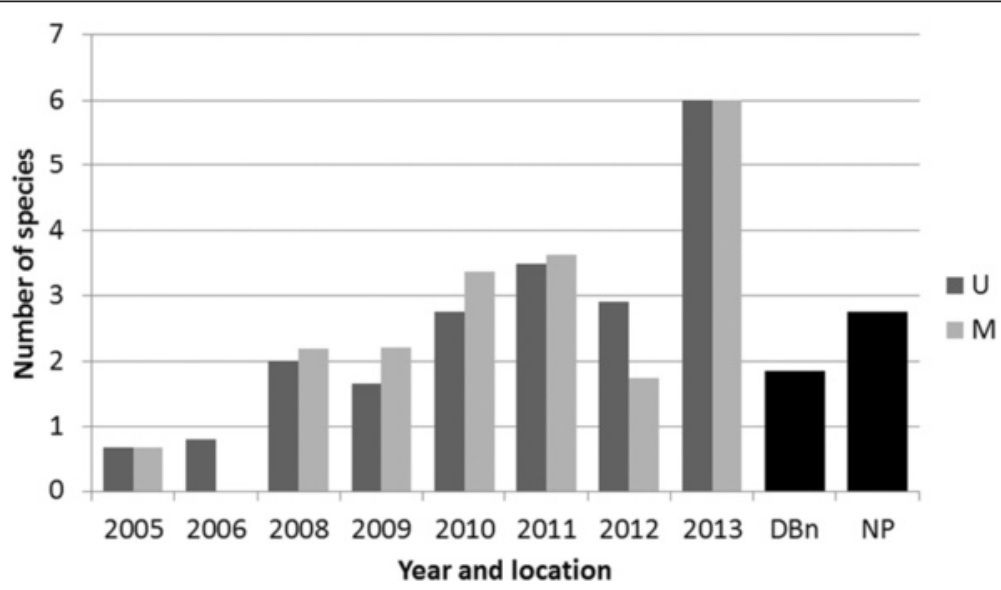

Figure 6 Average species richness per sample in every year in upper $(U)$ and mid-intertidal zones $(M)$ in mangrove plantation in Dam Bay, Nha Trang, central Vietnam, and two natural mangrove associations in Dam Bay (DBn) and Nha Phu (NP) which are in black. 
Table 3 Average abundance and biomass with standard deviation of the most common gastropod species in upper intertidal zone

\begin{tabular}{|c|c|c|c|c|c|c|c|c|c|}
\hline & \multicolumn{9}{|c|}{ Number of samples and the year of collection } \\
\hline & 3 & 5 & 3 & 7 & 8 & 8 & 7 & 8 & 7 \\
\hline & 2005 & 2006 & 2008 & 2009 & 2010 & 2011 & 2012 & 2013 & $\mathrm{DBn}$ \\
\hline Clithon oualaniense & $\frac{69.7 \pm 120.7}{14.3 \pm 24.8}$ & $\frac{346.7 \pm 530}{30.6 \pm 48.8}$ & $\frac{39.4 \pm 53.3}{2.5 \pm 4.3}$ & $\frac{74.3 \pm 146}{4.1 \pm 6.92}$ & $\frac{17.0 \pm 32.3}{1.8 \pm 3.34}$ & $\frac{46.6 \pm 73.4}{46.6 \pm 73.4}$ & $\frac{13.6 \pm 21.2}{0.5 \pm 0.8}$ & $\frac{226.1 \pm 242.5}{14.5 \pm 14.3}$ & \\
\hline Clithon faba & $\frac{18.2 \pm 31.5}{12.0 \pm 20.7}$ & & & & & & $\frac{1.1 \pm 3.2}{0.4 \pm 1.12}$ & $\frac{28.4 \pm 38.1}{2.5 \pm 3.5}$ & \\
\hline Cerithideopsilla cingulata & & & $\frac{60.6 \pm 105}{16.4 \pm 28.3}$ & $\frac{52.9 \pm 139.8}{4.3 \pm 11.3}$ & $\frac{183 \pm 289.1}{16.3 \pm 13.3}$ & $\frac{223.9 \pm 229.7}{62.5 \pm 50.9}$ & $\frac{190.9 \pm 150.9}{68.5 \pm 47.3}$ & $\frac{206.8 \pm 262}{47.9 \pm 58}$ & \\
\hline Batillaria zonalis & & & $\frac{90.9 \pm 142}{45.5 \pm 66}$ & $\frac{55.71 \pm 147.4}{2.7 \pm 7.3}$ & $\frac{239.8 \pm 255.3}{30.1 \pm 21.2}$ & $\frac{443.2 \pm 525.6}{109.5 \pm 111.1}$ & $\frac{944.3 \pm 650.6}{102.1 \pm 30.9}$ & $\frac{136.4 \pm 241.3}{84.7 \pm 184.4}$ & \\
\hline Cerithium coralium & & & & $\frac{127.1 \pm 183}{22.8 \pm 39.9}$ & $\frac{1.1 \pm 3.2}{0.5 \pm 1.5}$ & & $\frac{7.9 \pm 19.1}{2.6 \pm 4.3}$ & $\frac{5.7 \pm 12.8}{0.5 \pm 1.15}$ & $\frac{19.5 \pm 51.5}{13.9 \pm 43.5}$ \\
\hline Clypeomorus bifasciata & & & $\frac{3.0 \pm 5.2}{1.2 \pm 2.1}$ & $\frac{95.71 \pm 244.5}{21.4 \pm 54.2}$ & $\frac{6.8 \pm 9.7}{1.0 \pm 1.1}$ & $\frac{23.9 \pm 29.9}{5.1 \pm 7.4}$ & $\frac{4.5 \pm 6.9}{1.3 \pm 2.3}$ & $\frac{14.8 \pm 16.7}{1.6 \pm 1.9}$ & $\frac{28.6 \pm 37.3}{9.0 \pm 16.7}$ \\
\hline Total for common species & $\frac{87.9 \pm 152.2}{26.3 \pm 45.5}$ & $\frac{364.7 \pm 530}{30.6 \pm 48.8}$ & $\frac{193.9 \pm 153.3}{65.5 \pm 58.8}$ & $\frac{405.7 \pm 579}{55.4 \pm 94.8}$ & $\frac{447.7 \pm 524.8}{49.7 \pm 35}$ & $\frac{950 \pm 411.5}{218.9 \pm 115.7}$ & $\frac{660.2 \pm 595.3}{169.3 \pm 136.2}$ & $\frac{1426.1 \pm 908.9}{169.2 \pm 61.5}$ & $\frac{184.4 \pm 224.2}{120.7 \pm 154.5}$ \\
\hline Total for all species & $\frac{87.9 \pm 152.2}{26.3 \pm 45.5}$ & $\frac{364.7 \pm 527.2}{34 \pm 47}$ & $\frac{193.9 \pm 153.3}{65.5 \pm 58.8}$ & $\frac{408.6 \pm 583.7}{55.4 \pm 94.8}$ & $\frac{452.3 \pm 495.7}{52.9 \pm 39.1}$ & $\frac{955.7 \pm 421.5}{222.4 \pm 123.5}$ & $\frac{660.2 \pm 595.3}{169.3 \pm 136.2}$ & $\frac{1429.5 \pm 908.7}{170 \pm 57.5}$ & $\frac{192.2 \pm 224.1}{121.6 \pm 154.5}$ \\
\hline
\end{tabular}

Average abundance $\left(\mathrm{m}^{-2}\right.$, above line) and biomass ( $\mathrm{g} / \mathrm{m}^{2}$, below line) with standard deviation of the most common gastropod species (found in half or more sampling seasons) in quantitative samples and total abundance and biomass of gastropods in upper intertidal zone in each year of monitoring in mangrove plantations in Dam Bay and natural mangrove association in Dam Bay (DBn). 


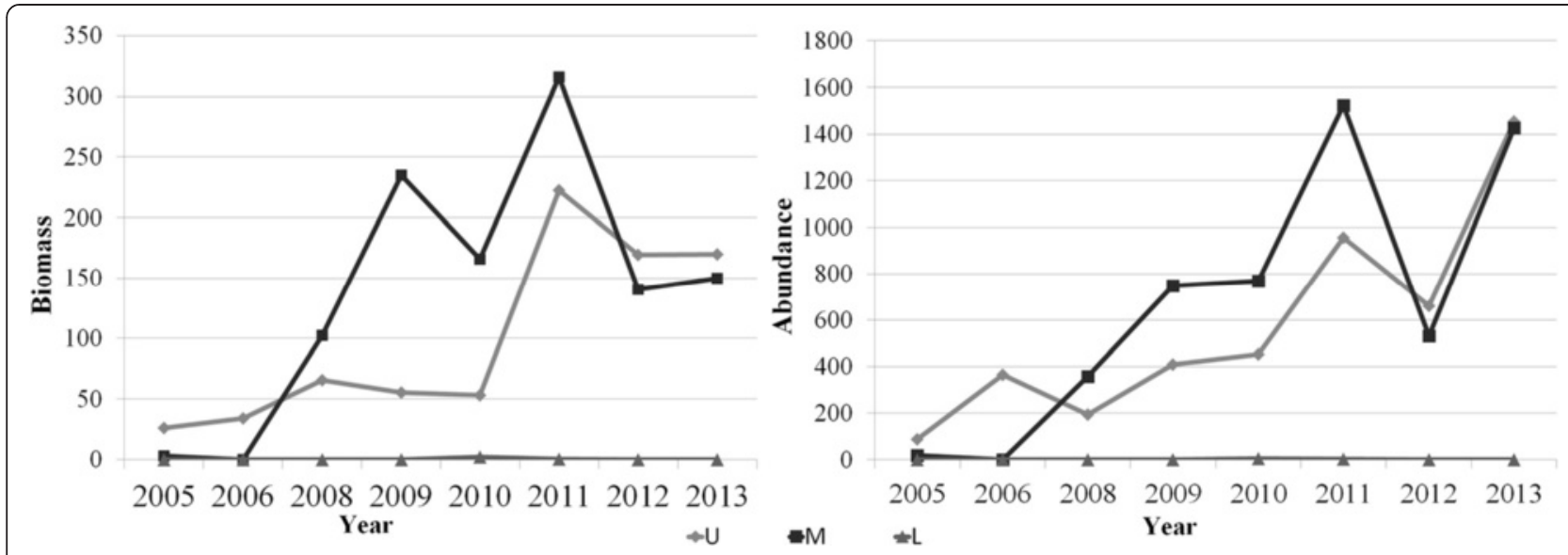

Figure 7 Biomass and abundance dynamics in upper (U), mid (M) and low (L) intertidal zones in mangrove plantation in Dam Bay, Nha Trang, central Vietnam.

The number of species recorded in this study is similar or even higher than in other areas of south-east Asia, for example, approximately 50 species were found in Malay peninsula (Ashton et al. 2003), 56 species were found in the Indian Sundarbans including areas adjacent to mangrove trees biotopes (Dey 2006), 30 gastropod species were found in natural and replanted mangroves on the west coast of Thailand (Macintosh et al. 2002), and 32 species were collected on the coast of south Thailand (Sri-aroon et al. 2005).

Probably the highest number, some 151 gastropod species in total, were found in mangroves of Abatan river on Bohol Island, Philippines (Lozouet and Plaziat 2008). The mentioned locality is characterized by a wide variety of habitats - from nearly freshwater, with Nypa palms, to typically full salinity marine areas. The authors restricted the number of species, which have been collected exclusively within mangroves to 65 , although due to a large number of singletons, this number is definitely an underestimation.

Species richness in planted mangroves in Dam Bay alone (30 species) increased significantly during monitoring years, with appearance in 2008 and slow growth of number of predominantly mangrove-associated species (Littoraria). Nevertheless, most of predominantly mangrove-associated species are still absent in Dam Bay plantation (e.g., Potamididae - Cerithideopsilla djadjariensis, C. microptera, Cerithidea quadrata, Terebralia spp., some others) despite their presence in natural association in Nha Phu and pelagic development (Houbrick 1991) that should facilitate the species dispersal. We are unable to account for the absence of these species in Dam Bay at the moment. It should be mentioned that the relatively high number of recorded species is due to the continuous observations, and in any given year, the number of collected species was much lower and never exceeded 19 (in 2011), thus making it the least rich in gastropods among all studied sites in the Nha Trang area.

In the natural mangrove association in Dam Bay, we found 19 gastropod species. This was 11 species less than the total number observed in the mangrove plantation, but the sampling efforts in the latter were considerably higher. The main difference in species composition between mangrove plantations and the natural mangrove association in Dam Bay was that species associated with intertidal rocks were absent in mangrove plantations, such as Pictocolumbella ocellata, Tenguella musiva, Drupella margariticola, Planaxis sulcatus, and Nerita undata. On the contrary, some species that were common in the plantations were absent in the natural association, such as Clithon oualaniensis and Cerithideopsilla cingulata. This could not be explained only by differences in abiotic factors between the sites, and this difference in species composition may be possibly related to the ecology of these species. Amongst the predominantly mangrove-associated gastropods, only two Littoraria species were found here.

Species diversity of Nha Phu (28 species in single collecting year) is much higher than in other sites and is comparable with the total number of species in mangrove plantation (collected in 2005 to 2013), though species composition is different here. The most diverse gastropod family in Nha Phu was the Potamididae, while in the mangrove plantation, only one species in this family was found. Most of the species of this family except Cerithideopsilla cingulata are considered as predominantly mangrove associated (Reid et al. 2008). Some species of Ellobiidae are considered as one of the main components of mangroveassociated gastropods (Reid et al. 2008, Reid et al. 2013), and they were present only in Nha Phu. These predominantly mangrove-associated species are mostly arboreal, and this can explain the fact that NP mangroves have lower average species richness, as shown by quantitative 
Table 4 Average abundance and biomass with standard deviation of the most common gastropod species in mid intertidal zone

\begin{tabular}{|c|c|c|c|c|c|c|c|c|c|}
\hline & \multicolumn{9}{|c|}{ Number of samples and the year of collecting } \\
\hline & 3 & 5 & 5 & 7 & 8 & 8 & 8 & 7 & 2 \\
\hline & 2005 & 2006 & 2008 & 2009 & 2010 & 2011 & 2012 & 2013 & NP \\
\hline Clithon oualaniense & & & $\frac{35.6 \pm 37.1}{2.7 \pm 3.3}$ & $\frac{165.7 \pm 267.4}{11.1 \pm 17.2}$ & $\frac{117.0 \pm 130.9}{8.7 \pm 9.8}$ & $\frac{404.5 \pm 625.6}{21.5 \pm 29.1}$ & $\frac{13.6 \pm 35}{1.0 \pm 1.8}$ & $\frac{374 \pm 186.5}{22.7 \pm 11.4}$ & $\frac{309.1 \pm 500.2}{23.0}$ \\
\hline Clithon faba & & & & & $\frac{1.1 \pm 3.2}{0.2 \pm 0.7}$ & $\frac{5.7 \pm 10.8}{1.0 \pm 2.4}$ & & $\frac{98.7 \pm 117.7}{5.5 \pm 8.3}$ & \\
\hline Cerithideopsilla cingulata & & & & & $\frac{6.8 \pm 12.6}{1.2 \pm 2.2}$ & $\frac{50.0 \pm 98.6}{19.3 \pm 39.8}$ & $\frac{18.2 \pm 41.5}{6.2 \pm 15.8}$ & $\frac{10.4 \pm 12.2}{4.1 \pm 4.2}$ & $\frac{1379.55 \pm 2070.6}{124.4}$ \\
\hline Batillaria zonalis & & & $\frac{247.8 \pm 378.2}{85.8 \pm 123.7}$ & $\frac{478.6 \pm 449.3}{192.3 \pm 189.4}$ & $\frac{576.1 \pm 421.5}{137.6 \pm 127.1}$ & $\frac{946.6 \pm 724.7}{256.3 \pm 197.3}$ & $\frac{484.1 \pm 634.2}{125.1 \pm 150.8}$ & $\frac{868.8 \pm 470.6}{142.9 \pm 75.4}$ & $\frac{2.27 \pm 4.5}{0.5}$ \\
\hline Cerithium coralium & & & & & $\frac{10.2 \pm 28.9}{10.2 \pm 27.1}$ & & $\frac{10.2 \pm 25.5}{7.5 \pm 19.1}$ & & \\
\hline Clypeomorus bifasciata & & & $\frac{70.8 \pm 80.4}{13.5 \pm 12.6}$ & $\frac{114.3 \pm 198.6}{25.2 \pm 50}$ & $\frac{54.5 \pm 73.4}{7.1 \pm 7.3}$ & $\frac{112.5 \pm 123.7}{17.4 \pm 26.6}$ & & & \\
\hline Total for common species & 0 & 0 & $\frac{354.2 \pm 485.5}{102 \pm 136.4}$ & $\frac{758.6 \pm 509.4}{223 \pm 203.5}$ & $\frac{765.9 \pm 493.1}{165.1 \pm 130.2}$ & $\frac{1519.3 \pm 1311.5}{315.5 \pm 216.6}$ & $\frac{528.4 \pm 688.6}{140 \pm 163.3}$ & $\frac{1416.9 \pm 614.1}{186.1 \pm 76}$ & $\frac{1690.9 \pm 2000.2}{147.9 \pm 157.3}$ \\
\hline Total for all species & $\frac{18.2 \pm 24.1}{3 \pm 2.7}$ & 0 & $\frac{357.9 \pm 482.4}{102.4 \pm 136}$ & $\frac{762.9 \pm 507.3}{230.1 \pm 199}$ & $\frac{768.2 \pm 494}{165.8 \pm 130.2}$ & $\frac{1523.9 \pm 1313.8}{315.6 \pm 216.6}$ & $\frac{530.7 \pm 688.7}{140.4 \pm 163.6}$ & $\frac{1440.3 \pm 606}{210 \pm 80}$ & $\frac{1715.9 \pm 1993.7}{148.8 \pm 157.3}$ \\
\hline
\end{tabular}

Average abundance ( $\mathrm{m}^{-2}$, above line) and biomass ( $\mathrm{g} / \mathrm{m}^{2}$, below line) with standard deviation of the most common gastropod species (found in half or more sampling seasons) in quantitative samples and total abundance and biomass of gastropods in mid intertidal zone in each year of monitoring in mangrove plantations in Dam Bay and natural mangrove association in Nha Phu (NP). 
samples taken on the surface of sediments (only 2.8 species per sample) comparing with DB (six species per sample in year 2013).

A possible explanation of the absence of key groups of predominantly mangrove-associated gastropod species in both study areas in Dam Bay may be due to differences in the types of vegetative associations in Dam Bay and Nha Phu. In Dam Bay, the mangrove trees comprise small monospecific associations, while at Nha Phu the mangrove association has more complex vegetation structure, which is also much larger than both associations in Dam Bay and experiences a wider range of hydrological conditions. This confirms the statement of Macintosh et al. (2002) about the correlation between the diversity of mangrove vegetation and mangal-associated fauna.

\section{Biomass and abundance of Gastropoda}

Only gastropods that inhabit the surface of the substratum were used for analysis of biomass and abundance and therefore the following discussion has some limitations, since most of predominantly mangrove-associated species (mostly living on the roots and branches of the mangrove trees) were not quantitatively sampled.

The mangrove plantation in Dam Bay is characterized by high level of micro heterogeneity. This is confirmed by very high values of standard deviation in biomass and abundance indexes. The abundance of gastropods strongly depends on proximity of the frame to the nearest tree. In general, the samples, collected in close proximity, were poorer than samples taken at some distance from the trees (pers. obs.). This heterogeneity obscures the general tendencies. In the discussion below, we used the average values of biomass and abundance.

In the upper intertidal zone, biomass and abundance varied from year to year and both parameters significantly increased during monitoring period (Figure 7). In later years, biomass and abundance of Batillaria zonalis and Cerithideopsilla cingulata were relatively high, while in the early years (2005 to 2006), the two species were absent. One might expect that the parameters would remain stable, since no changes in vegetation happened in the upper intertidal zone over the period of observation. Thus, the changes in gastropod population parameters in the upper intertidal zone may have been caused by changes in the mid-intertidal zone after planting the mangrove seedlings, and where biomass and abundance of gastropods, especially of $B$. zonalis and $C$. cingulata, increased even more dramatically in the later period of monitoring. Low biomass and abundance or even absence of gastropod molluscs in mid-intertidal zone in 2005 to 2006 can be explained by the fact that molluscs just started to populate the young plantation.

Both in upper and mid-intertidal zones in late period (2008 to 2013), biomass and abundance of gastropods increased due to Batillaria zonalis and Clithon oualaniensis. Batillaria zonalis, Cerithideopsilla cingulata, and C. oualaniensis occur in different habitats in addition to the mangal - in fish ponds, estuarine systems, intertidal muddy, and sand banks sometimes in high densities (Vohra 1970; Grüneberg and Nugaliyadde 1976; Kamimura and Tsuchiya 2004; Fujioka et al. 2007; Tan and Clements 2008). In the mangrove plantation, these species can be considered as opportunistic. They penetrated the mid-intertidal zone in Dam Bay with the appearance of mangrove vegetation providing enrichment of detritus and conditions suitable for the growth of micro-algae on which these species feed (Kamimura and Tsuchiya 2004; Vohra 1970).

The facts that the mangrove plantation in Dam Bay is highly dominated by opportunistic species together with paucity of predominantly mangrove-associated gastropods suggest that the whole ecosystem is not balanced yet. Macintosh et al. (2002) obtained a similar result - the species diversity indexes were lower, and abundance was higher in planted mangroves than in mature mangroves. Therefore, we can expect that biomass and abundance of these species eventually will reach a plateau and may even decrease as the whole system reaches an equilibrium.

In the natural mangrove association in Dam Bay, the dominant species was the same as in the plantation Batillaria zonalis. Although this species occurred in comparatively lower density in the natural mangrove, its biomass was comparable with that of the mangrove plantation, due to larger sizes of individuals in DBn. Two other most abundant species in the plantation, namely Cerithideopsilla cingulata and Clithon oualaniensis were absent in the natural mangrove. This difference can probably be explained by unequal amount of organic matter in the substratum of these two associations. Since the natural association in Dam Bay is represented only by a narrow belt of trees, large amounts of organic matter are washed away by tides, while in thicker mangrove plantations, it is reposed, thus allowing opportunistic species to attain high densities. Since this natural association corresponds to the upper intertidal zone of the mangrove plantation area with mature Rhizophora trees, the low abundance of opportunistic species confirms the fact that mid-intertidal zone is strongly affecting the fauna of upper intertidal zone. Cerithideopsilla cingulata and Clithon oualaniensis also dominated quantitative samples collected in Nha Phu. This suggests that the natural mangrove association despite its richness in gastropods is unbalanced too. One of the reasons may be the inputs from eutrophicated ponds through the channels in the natural mangrove vegetation.

\section{Conclusions}

Nine-year-old mangrove plantation differed from natural mangrove association in biomass and abundance. Species diversity in plantations increased through the monitoring 
period but it is dominated by opportunistic eurybiotic gastropod species. This suggests that the ecosystem is still in a transitional state.

This investigation is the first study of gastropod molluscs in mangroves of central Vietnam, and it is one of the first long-term monitoring studies in the newly planted mangroves. The findings of this study potentially can make a contribution to understanding of establishing of mangrove ecosystem and highlighted the parameters in evaluating the state of the mangrove ecosystem.

\section{Competing interests}

The authors declare that they have no competing interests.

\section{Authors' contributions}

ZSS, KYI, BTA, and XL collected and processed the samples, analyzed the results, and wrote the manuscript. All authors read and approved the final manuscript.

\section{Authors' information}

ZSS is a PhD student in the Laboratory of Ecology and Morphology of Marine Invertebrates; this study is a part of $\mathrm{PhD}$ thesis.

$\mathrm{KY}$ is a PhD, DSc, leading researcher, and scientific advisor of ZSS.

BTA is a PhD, DSc, Prof., and director of the Laboratory of Ecology and Morphology of Marine Invertebrates.

$\mathrm{XL}$, with a degree in $\mathrm{PhD}$, is a research professor.

\section{Acknowledgements}

We would like to thank our colleagues from A.N. Severtsov Institute of Ecology and Evolution Yu.V. Deart, Yu. Dgebuadze, A.E. Fedosov, I.N. Marin, P, E.S. Mekhova, and A.V. Zykova; colleagues from Moscow State University E.V. Vortsepneva and A.E. Zhadan; B.I. Sirenko from Zoological Institute; and A.A. Udalov from P.P. Shirshov Institute of Oceanology for their assistance in field work and data analysis. The fieldwork in Vietnam was supported by the Coastal Branch of the Russian Vietnamese Tropical Center (Nha Trang, Vietnam), and we also thank colleagues from Tropical Centre Vo Thi Ha, Nguyen Thi Hai Thanh, Tran Quoc Hoan, and Nguyen Van Quang for their assistance in organizing and conducting material collecting. The work was partially supported by the grants of Russian Foundation for Basic research 13-04-91175-GFEN_a 'Mangrove ecosystems of South China Sea: degradation and rehabilitation' and 14-04-00481-a.

\section{Author details}

'Laboratory of Ecology and Morphology of Marine Invertebrates, A.N. Severtsov Institute of Ecology and Evolution, 33 Leninskij prosp, Moscow 119071, Russia. ${ }^{2}$ Institute of Oceanology, Chinese Academy of Sciences, 7 Nanhai Road, Qingdao, 266071, China.

Received: 1 September 2014 Accepted: 29 April 2015

Published online: 12 May 2015

\section{References}

Alongi D, Johnston D, Xuan T (2000) Carbon and nitrogen budgets in shrimp ponds of extensive mixed shrimp-mangrove forestry farms in the Mekong Delta, Vietnam. Aquac Res 31:387-399

Amano T, Yoshinaga I, Yamagishi T (2009) Contribution of anammox bacteria to benthic nitrogen cycling in a mangrove forest and shrimp ponds, Haiphong, Vietnam. Microbes Environ 26:1-6, doi:10.1264/jsme2.ME10150

Ashton EC, Macintosh DJ, Hogarth P (2003) A baseline study of the diversity and community ecology of crab and molluscan macrofauna in the Sematan mangrove forest, Sarawak, Malaysia. J Trop Ecol 19:127-142

Berger U, Rivera-Monroy VH, Doyle TW, Dahdouh-Guebas F, Duke NC, FontalvoHerazo ML, Hildenbrandt H, Koedam N, Mehlig U, Piou C, Twilley RR (2008) Advances and limitations of individual-based models to analyze and predict dynamics of mangrove forests: a review. Aquat Bot 89:260-274, doi:10.1016/j.aquabot.2007.12.015

Berry AJ (1963) Faunal zonation in mangrove swamps. Bull Natl Museum State Singapore 32:90-98
Binh CT, Phillips MJ, Demaine H (1997) Integrated shrimp-mangrove farming systems in the Mekong delta of Vietnam. Aquac Res 28:599-610

Binh TNKD, Vromant N, Hung NT, Hens L, Boon EK (2005) Land cover changes between 1968 and 2003 in Cai Nuoc, Ca Mau Peninsula, Vietnam. Environ Dev Sustain 7:519-536, doi:10.1007/s10668-004-6001-z

Bosire JO, Dahdouh-Guebas F, Kairo JG, Cannicci S, Koedam N (2004) Spatia variations in macrobenthic fauna recolonisation in a tropical mangrove bay Biodivers Conserv 13:1059-1074, doi:10.1023/B:BIOC.0000018149.88212.2d

Bouillon S, Koedam N, Raman A, Dehairs F (2002) Primary producers sustaining macro-invertebrate communities in intertidal mangrove forests. Oecologia 130:441-448, doi:10.1007/s004420100814

Cantera J, Arnaud PM, Thomassin BA (1983) Biogeographic and ecological remarks on molluscan distribution in mangrove biotopes. 1. Gastropods. J Molluscan Stud Suppl 12A:10-26

Christensen S, Tarp P, Hjortsø C (2008) Mangrove forest management planning in coastal buffer and conservation zones, Vietnam: a multimethodological approach incorporating multiple stakeholders. Ocean Coast Manag 51:712-726, doi:10.1016/j.ocecoaman.2008.06.014

De Graaf G, Xuan T (1998) Extensive shrimp farming, mangrove clearance and marine fisheries in the southern provinces of Vietnam. Mangroves Salt Marshes 2:159-166

Dey A (2006) Handbook on mangrove associate molluscs of Sundarbans. Zoological survey of India, Kolkata

Dittmann S (2000) Zonation of benthic communities in a tropical tidal flat of north-east Australia. J Sea Res 43:33-51, doi:10.1016/S1385-1101(00)00004-6

Ellison AM, Farnsworth EJ, Merkt RE (1999) Origins of mangrove ecosystems and the mangrove biodiversity anomaly. Global Ecol Biogeogr 8:95-115, doi:10.1046/j.1466-822X.1999.00126.X

Fujioka Y, Shimoda T, Srithong C (2007) Diversity and community structure of macrobenthic fauna in shrimp aquaculture ponds of the Gulf of Thailand. Japan Agric Res 41:163-172

Grüneberg H, Nugaliyadde L (1976) Population studies on a polymorphic prosobranch snail (Clithon (Pictoneritina) oualaniensis Lesson). Philos Trans $\mathrm{R}$ Soc Lond B Biol Sci 275:385-437

Hong PN (2004) Effects of mangrove restoration and conservation on the biodiversity and environment in Can Gio District. In: Vanucci M (ed) Mangrove Management and Conservation: Present and Future. NY United Nations University Press, New York, pp 111-137

Hong PN, San HT (1993) Mangroves of Vietnam. IUCN, Bangkok

Houbrick RS (1985) Genus Clypeomorus Jousseaume (Cerithiidae - Prosobranchia). Smithson Contrib Zool 403:1-131

Houbrick RS (1991) Systematic review and functional morphology of the mangrove snails Terebralia and Telescopium (Potamididae; Prosobranchia). Malacologia 33:289-338

Houbrick RS (1992) Monograph of the Genus Cerithium Bruguiere in the Indo-Pacific (Cerithiidae - Prosobranchia). Smithson Contrib Zool 510:1-211

Hylleberg J, Kilburn RN (2003) Marine molluscs of Vietnam (Tropical marine mollusc program). Phuket Mar Biol Cent Spe Pub 28:1-300

Johnston D, Trong NV, Tien DV, Xuan TT (2000) Shrimp yields and harvest characteristics of mixed shrimp-mangrove forestry farms in southern Vietnam: factors affecting production. Aquaculture 188:263-284

Kamimura S, Tsuchiya M (2004) The effect of feeding behavior of the gastropods Batillaria zonalis and Cerithideopsilla cingulata on their ambient environment. Mar Biol 144:705-712, doi:10.1007/s00227-003-1238-x

Kristensen E, Bouillon S, Dittmar T, Marchand C (2008) Organic carbon dynamics in mangrove ecosystems: a review. Aquat Bot 89:201-219, doi:10.1016/ j.aquabot.2007.12.005

Lan T, Trang C, Huong D, Cuong C, Vinh V (2012) Sustainability in coastal urban environment: thematic profiles of resources and their users. Case studies of Hai Phong and Nha Trang City-Vietnam. SECOA FP7 Res. Proj. Vol. 3. Sapienza Universita Editrice, Rome, pp 301-343

Le Vay L, Ut V, Jones D (2001) Seasonal abundance and recruitment in an estuarine population of mud crabs, Scylla paramamosain, in the Mekong Delta, Vietnam. Hydrobiologia 449:231-239

Lee SY (2008) Mangrove macrobenthos: assemblages, services, and linkages. J Sea Res 59:16-29, doi:10.1016/j.seares.2007.05.002

Lozouet P, Plaziat J-C (2008) Mangrove environments and mollusks Abatan River, Bohol and Panglao Islands. ConchBooks, Hackenheim, Central Philippines

Macintosh DJ, Ashton EC, Havanon S (2002) Mangrove rehabilitation and intertidal biodiversity: a study in the Ranong mangrove ecosystem, Thailand. Estuar Coast Shelf Sci 55:331-345, doi:10.1006/ecss.2001.0896 
Macnae W (1968) A general account of the fauna and flora of mangrove swamps and forests in the Indo-West-Pacific region. Adv Mar Biol 6:73-270

Martins AM d F (1996) Relationships within the Ellobiidae. In: Taylor J (ed) Orig. Evol. Radiat. Mollusca. Oxford University Press, Oxford, pp 285-294

Metcalfe KN, Glasby CJ (2008) Diversity of Polychaeta (Annelida) and other worm taxa in mangrove habitats of Darwin Harbour, northern Australia. J Sea Res 59:70-82, doi:10.1016/j.seares.2007.06.002

Nagelkerken I, Blaber SJM, Bouillon S, Green P, Haywood M, Kirton LG, Meynecke JO, Pawlik J, Penrose HM, Sasekumar A, Somerfield PJ (2008) The habitat function of mangroves for terrestrial and marine fauna: a review. Aquat Bot 89:155-185, doi:10.1016/j.aquabot.2007.12.007

Ng PKL, Sivasothi N (1999a) A guide to the mangroves of Singapore 1. Singapore Science Centre, Singapore

Ng PKL, Sivasothi N (1999b) A guide to the mangroves of Singapore 2. Singapore Science Centre, Singapore

Okutani T (2000) Marine mollusks in Japan. Tokai University Press, Tokyo

Poppe GT (2008a) Volume I: Philippine marine mollusks. ConchBooks, Hackenheim

Poppe GT (2008b) Volume II: Philippine marine mollusks. ConchBooks, Hackenheim

Poppe GT (2010) Volume III: Philippine marine mollusks. ConchBooks, Hackenheim

Printrakoon C, Wells F, Chitramvong Y (2008) Distribution of molluscs in mangroves at six sites in the upper Gulf of Thailand. Raffles Bull Zool 18:247-257

Reid DG (1986) The littorinid molluscs of mangrove forests in the Indo-Pacific region:the genus Littoraria. British Museum (Natural History), London

Reid DG, Dyal P, Lozouet P, Glaubrecht M, Williams ST (2008) Mudwhelks and mangroves: the evolutionary history of an ecological association (Gastropoda: Potamididae). Mol Phylogenet Evol 47:680-699, doi:10.1016/j.ympev.2008.01.003

Reid DG, Claremont M, Smith L, Shamoto M, Glaubrecht M, Ozawa T (2013) Mosaics in the mangroves: allopatric diversification of tree-climbing mudwhelks (Gastropoda: Potamididae: Cerithidea) in the Indo-West Pacific. Biol J Linn Soc 110:564-580, doi:10.1111/bij.12151

Sasekumar A (1974) Distribution of macrofauna on a Malayan Mangrove Shore. J Anim Ecol 43:51-69

Skilleter GA (1996) Validation of rapid assessment of damage in urban mangrove forests and relationships with molluscan assemblages. J Mar Biol Assoc UK 76:701-716

Skilleter GA, Warren S (2000) Effects of habitat modification in mangroves on the structure of mollusc and crab assemblages. J Exp Mar Bio Ecol 244:107-129, doi:10.1016/S0022-0981(99)00133-1

Sri-aroon P, Lohachit C, Harada M (2005) Brackish-water mollusks of Surat Thani Province, southern Thailand. Southeast Asian J Trop Med Public Health 36:180-188

Tan SK, Clements R (2008) Taxonomy and distribution of the Neritidae (Mollusca: Gastropoda) in Singapore. Zool Stud 47:481-494

Thu PM, Populus J (2007) Status and changes of mangrove forest in Mekong Delta: case study in Tra Vinh, Vietnam. Estuar Coast Shelf Sci 71:98-109, doi:10.1016/j.ecss.2006.08.007

Tue NT, Hamaoka H, Sogabe A, Quy TD, Nhuan MT, Omori K (2012) Food sources of macro-invertebrates in an important mangrove ecosystem of Vietnam determined by dual stable isotope signatures. J Sea Res 72:14-21, doi:10.1016/.jseares.2012.05.006

Vohra FC (1970) Some studies on Cerithidea cingulata (Gmelin 1790) on a Singapore sandy shore. J Molluscan Stud 39:187-202

\section{Submit your manuscript to a SpringerOpen ${ }^{\circ}$ journal and benefit from:}

- Convenient online submission

- Rigorous peer review

- Immediate publication on acceptance

- Open access: articles freely available online

- High visibility within the field

- Retaining the copyright to your article

Submit your next manuscript at $\gg$ springeropen.com 